\title{
Craft Entrepreneurship on Environmental Waste Recycling in Malang Municipality
}

\author{
Sri Muljaningsih* \\ Faculty of Economics and Business, University of Brawijaya, Indonesia
}

\begin{abstract}
The purpose of this study is to examine the effectiveness of Sanggar Asta Karya Panca Wiguna (AKPW) in Malang Municipality, Indonesia, in garbage-recycling business. Garbage has been turned into valuable and artistic products that is also environmentally friendly. The products produced include dammar kambang, suket wayang, lampshade, and others. This study uses qualitative method to examine the entrepreneurship behaviour of the AKPW. The key informant is the chairperson of the studio. AKPW works in the fields of environment, education, economy, culture, and health. The result of the research shows that the garbage-recycling business takes creativity and product innovation based on persistence and perseverance. AKPW works on the concept of social green entrepreneurship that combines the concept of three pillars of ecological, economic, and social sustainability through art and culture. AKPW should conduct more efforts to socialize more intensively.
\end{abstract}

Keywords: Garbage-recycling, creativity, innovation, AKPW, social entrepreneurship, Malang

\section{Introduction}

Waste generation increases rapidly along with population growth - given the development of urban population in Indonesia per year by $4 \%$. Based on Indonesia Garbage Statistics (KLH, 2008), the waste produced per person per day in Indonesia is $0.45 \mathrm{~kg}$. Thus, the existing waste generation in Indonesia multiplies along with the population growth of Indonesia. If the population of Indonesia is 231.8 million, then the amount of waste is 104.31 million $\mathrm{kg}$ /day. However, the ability or capacity of final landfill (TPA) is limited, that it can only accommodate about $30 \%$ of the total waste.

In Java, the population is 137.2 million people. The total waste generated is 21.2 million tons/year or $0.42 \mathrm{~kg} / \mathrm{day} /$ person. The actual ability to transport waste is 12.49 million tons/year, with the total population that can be served 80.8 million people. Thus, waste not transported is 8.71 million tons/year (KLH, 2008). This problem must be addressed properly.

Malang is located in East Java Province, with total population of 807.136 people, with growth rate $3.9 \%$ per year (KLH, 2008). This has an impact on the amount of waste generation in Malang, where based on data from Sanitation Department of Malang (Muljaningsih and Manzilati, 2001) the volume of waste is $1,790.5 \mathrm{~m}^{3}$. The existing types of waste include organic and non-organic waste such as paper, plastic, glass, metal and others. The highest volume of garbage is organic waste and the second is paper waste. Nevertheless, plastic and glass waste is also increasing.

Waste should be managed properly. Organic waste can be used as compost and non-organic waste can be recycled. Malang has applied the concept of 3R (Reduce, Re-Use, Re-Cycle) in waste management, and the implementation of the concept needs participation from the community. One group of people who care to recycle non-organic waste (plastic and glass) into handicraft is Sanggar

\footnotetext{
* Corresponding author at Jl. Veteran Malang, Ketawanggede, Kec. Lowokwaru, Kota Malang, Jawa Timur 65145, Indonesia. Email: muljaningsih@ub.ac.id
} 
Asta Karya Panca Wiguna (AKPW). AKPW has the concept of care for the environment, education, culture, economy, and health. This is in line with the sustainable entrepreneurship and innovation proposed prioritizing awareness to the community as well as the ecology. A model of sustainable social entrepreneurship is then made although in practice it is full of challenges. Therefore, entrepreneurs are not only considered as contributors in a successful economy, but also provide the power for sustainable community empowerment (Tilley and Young, 2009).

Based on the afore-mentioned description, the research objective is formulated, i.e. to examine the work of AKPW in applying the model of sustainable social entrepreneurship. Thus, this study aims to know the transfer of knowledge and technology transfer sustainable environmentally and ecologically, socially and culturally to support the creativity and awareness of the community of AKPW.

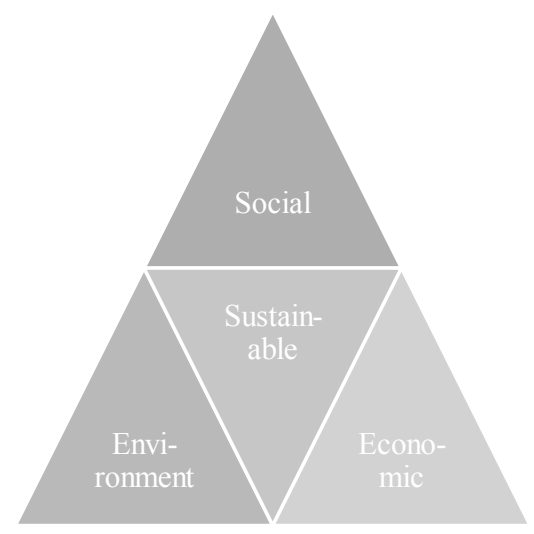

Figure 1. The Three Pillars of Sustainability

Given the object of this study is the AKPW community, the study seeks to review the economic and social conditions and the environment to be examine under the rules of green entrepreneurship. This is because AKPW is a business unit that produces environmentally friendly recycled handicraft. This community represents the principle of sustainability related to the environment and beneficial to the contribution of economic income; the community also cares about the condition of society through education and training.

In an integrated system of logistic management to recycle wastes means to avoid pollution or ecosystem damage. Integration here means that among the disposable goods of a company or factory, the recycling process is related to each other. It has a purpose for both the environment and the economy. By recycling, it will minimize waste, so it can extend the life of a product. The various forms of recycling are shown in Figure 2 (Callan and Thomas, 2000).

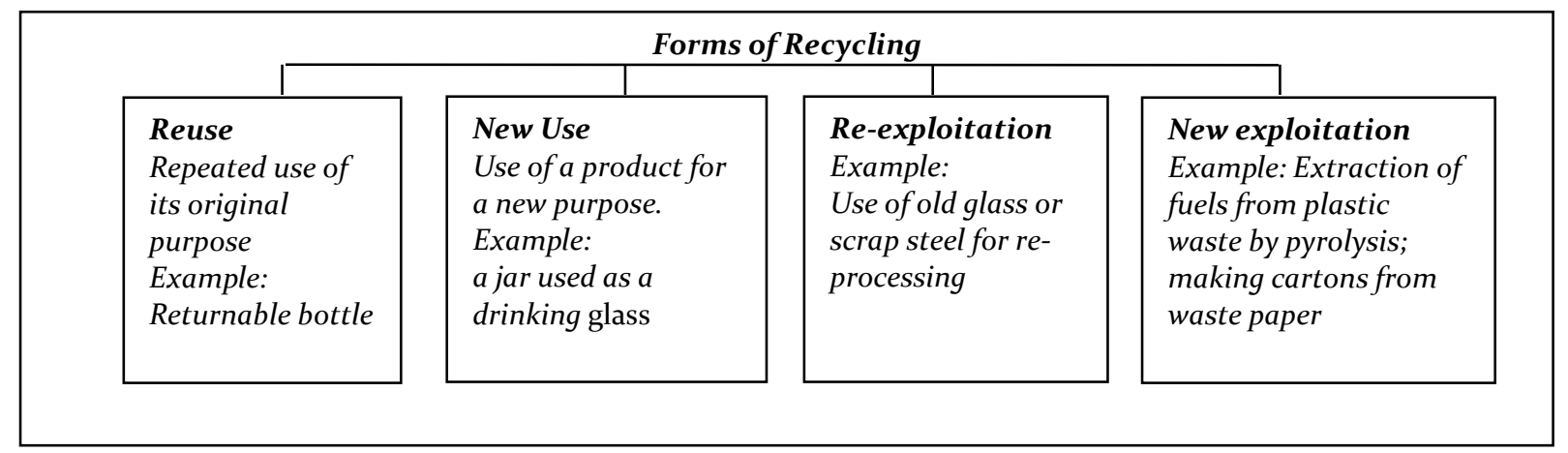

Figure 2. Forms of Recycling 
The household economic theory can be shown in Figure 3 as follows.

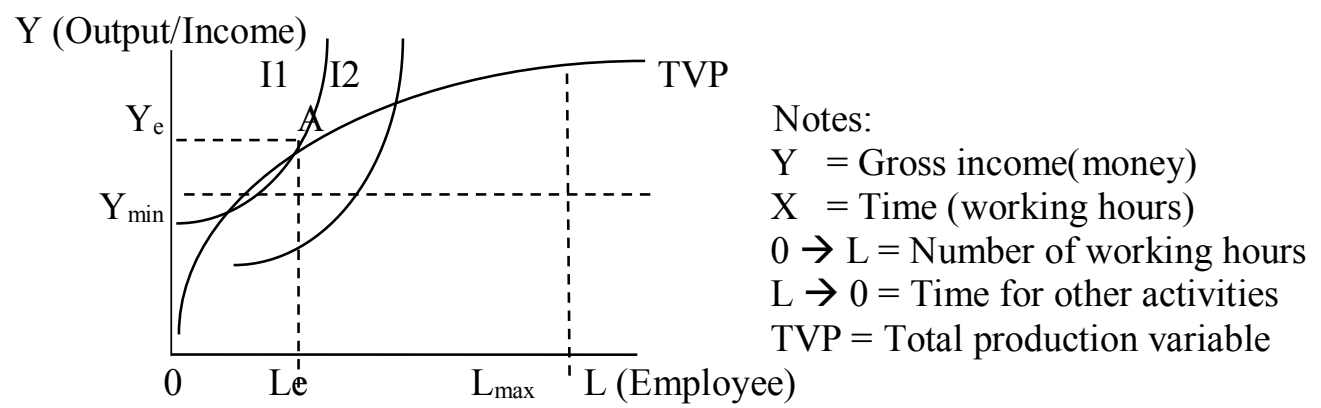

Figure 3. Household Income of Craftsman

TVP can be said as family income, which describes the production function, namely $\mathrm{Y}=\mathrm{Py}$. F (L). The consumption function is described in the form of indifference curve (I1 and I2) with utility function, namely $\mathrm{U}=\mathrm{f}(\mathrm{Y}, \mathrm{H})$, meaning that there is the choice between work $(\mathrm{Y})$ and having fun $(\mathrm{H})$. Therefore, the craftsman's household must be in Y minimum position, representing the income level to survive. Then to reach $\mathrm{Y}$ maximum, the craftsman will devote maximum working time (L max), meaning that they will sacrifice the having fun time. To be able to attain a balance position on Ye and Le at point A, addition must be made on the time to work and to have fun. Thus, point A denotes MVPL (Marginal Product of Labor) i.e. the equation $(\mathrm{dY} / \mathrm{dH})$; furthermore, it can be concluded that MUH $\mathrm{MUY}=\mathrm{dY} / \mathrm{dH}=\mathrm{MVPL}$, the microeconomic theory of craftsman's household behaviour is maximizing utility with three constraints including production function, minimum income level, and maximum number of available working days.

The object of this study is the community of AKPW interested in entrepreneurship of recycling handicraft from waste related to the concept of green entrepreneurship. Thus, we discuss intention of green entrepreneurship. It is part of the theory of green economics and ecology economics, which involves the rules of entrepreneurial behaviours (Kahan, 2012). Then methodologically to relate these three basic theories, the present study is adopting environmental management techniques, in accordance with the concept of ISO 14001 (International Standards Organization). It is expected that the study can provide optimal results for the interests of all parties concerned (social, economic, and environmental). Then the resulting product should provide added value to all stakeholders (Bragiunsky et al., 2009). The principle of added value is inseparable with the principle of innovation that has the element of innovation.

Assessment on the entrepreneurship behaviours of the community is through treatment (education and training) by performing various practices of manufacturing recycled handicraft products. This must reveal the principle of sustainability related to ecological safety, as well as beneficial to increase member's income, that is to become a recycled handicraft entrepreneur. This refers to the theory of Planned Behaviour, related to the psychological element (physiology), and is supported by the concept of entrepreneurship (Ajzen and M.Fishbein, 2000).

Schumpeter is famous for his theory on the role of entrepreneurs at the time of capital evolution, resulting in an innovation economy. Innovation economy aims to introduce new products and methods, open new markets or find new sources of supply, or create an organization of new industries, when associated with the definition of new products for environmental purposes. Another researched, continued the development of Schumpeter's thought, saying that if there is no technological innovation, decreased output and slow productivity growth will take place - this is environmental policy. The consequence of social costs that exceed private costs is the relocation of industrial activities. Therefore, it needs innovation of environmentally friendly technology (Roedigar and Schluga, 2004).

Entrepreneurs are creative and innovative human beings, becoming the fuel for the economic growth of society, as they have the ability to think and act productively. Entrepreneurial growth is highly correlated with economic growth, as employment opens, increasing public incomes, increasing 
purchasing power, and increasing sales on goods and services produced by the industry. Entrepreneur is always action-oriented, not theory-cantered-they are more practical, more work than talk. They have dreams and believe in the dreams as a source of energy for generating their motivation and vision. Their ideas may sound crazy, yet they work on those and make them real. Creativity requires a process through formal education, training, and work experience.

The key to success of an entrepreneur is to have an intelligence failure. Most people cannot stand the failure and they give up quickly - these people are not entrepreneurs. We learn from our failure and experience. Failure can trigger quality product innovation related to art. Therefore, entrepreneurs must be creative and resilient, and must conduct research well.

The principle of AKPW is entrepreneurship and innovation oriented towards ecological sustainability and care about social condition of society through training and education. Thus, it becomes social entrepreneurship and sustainability. In economic theory, entrepreneurs are generally viewed as individuals with exceptional qualities who are motivated to start a new business or organization or to revitalize a mature organization generally and in response to identified opportunities. While the lure of profit and market share is the primary motivator of individual entrepreneurs, an evolving academic literature explores alternative conceptualization of entrepreneurship involving more diverse motivations and broader social, political, and ecological context (Chell, 2007).The term social entrepreneurship is used to refer to people who create social entrepreneurial organizations or who seek to revitalize existing organizations; although social entrepreneurship is increasingly understood as a creative process that becomes the exclusive domain of the heroic and charismatic individual, involving the 'ideas generated, disseminated, and operationalized by groups, networks, and formal or informal organizations (Tilley and Young, 2009). In practice, the behaviours and operation of some privatesector businesses may be difficult to distinguish from social entrepreneurs. Therefore, it is important to investigate the motivations, ideas, actions, and experiences of the people involved in the entrepreneurial process and the context in which they operate, as well as the form of the organizations involved. A recent literature specifically concerned with entrepreneurship motivated by environmental values name it in various terms, such as environmentally sound or green, eco-enviropreneurship (Isaak, 2002), sustainable entrepreneurship (Dean and McMullan, 2007) and entrepreneurial sustainability (O'Neill et al., 2009; Tilley and Young, 2009). There is also traditional entrepreneurial model for profit and nonprofit (O'Neill et al., 2009; Tilley and Young, 2009). This alternative of sustainability entrepreneurship model is presented as a framework to guide individuals about the value and actions needed to start a sustainable business. "It is challenging to be realized in practice because of the many theoretical elements, but entrepreneurs have the ideal characteristics needed to experiment, risk, and practice the elements of this model and move towards entrepreneurship sustainability. Therefore, entrepreneurs should not only be regarded as contributors in a successful economy, but also a sustainable driving force of society" (Tilley and Young, 2009).

\section{Research Method}

This study uses qualitative approach. The object is Sanggar AKPW in Malang. The research focuses on creativity to produce innovative craft products made from non-organic waste. Key informant is Mrs. Suli, as the chairperson of AKPW. AKPW has eight (8) personnel. The focus of the research is to review the activities undertaken by AKPW. Data collection is done through conducting in-depth interviews.

Method of measuring indicator of achievement is based on indicator of interest referring to intention theory proposed by Ajzen and Fishbein (2000), i.e. attitude, subjective norm, and perception of behaviours control. The research by (Gordon, 2011) states the behavioural indicators as follows:

- Personal factors such as level of knowledge or education, attitudes, habits and routines, past experiences, socio-demographic factors, and so on.

- Social factors related to other people's influence on behaviour, cultural and social norms, tribal factors across geographical boundaries, and others.

- Environmental factors related to where a person lives and works, as well as broader factors such as economics, technology, population density, and so on. 
This research explores information from key informants by using in-depth interview method. The results are expected to produce a combination of three sustainability models and entrepreneurial behaviours theory.

\section{Result \& Discussion}

\section{Overview of Sanggar Asta Karya Panca Wiguna}

The chairperson is Mrs. Sulaihah, usually called as Mrs. Suli. She was born on April 3, 1969. She used to be a teaching staff at Madrasah Aliyah Negeri Bangil from 1996 to 2003. She also learned at Pasar Sulam from 2003 to 2015. She is experienced in giving trainings. She is the founder of AKPW. The activities AKPW done involved the followings:

- productive economic activities

- socio-cultural based activities

- environmental based activities

- inter-religion religious activities

- health-based activities

The study focuses on the productive economic, socio-cultural, and environmental activities of AKPW. Here are the recycled products of AKPW.

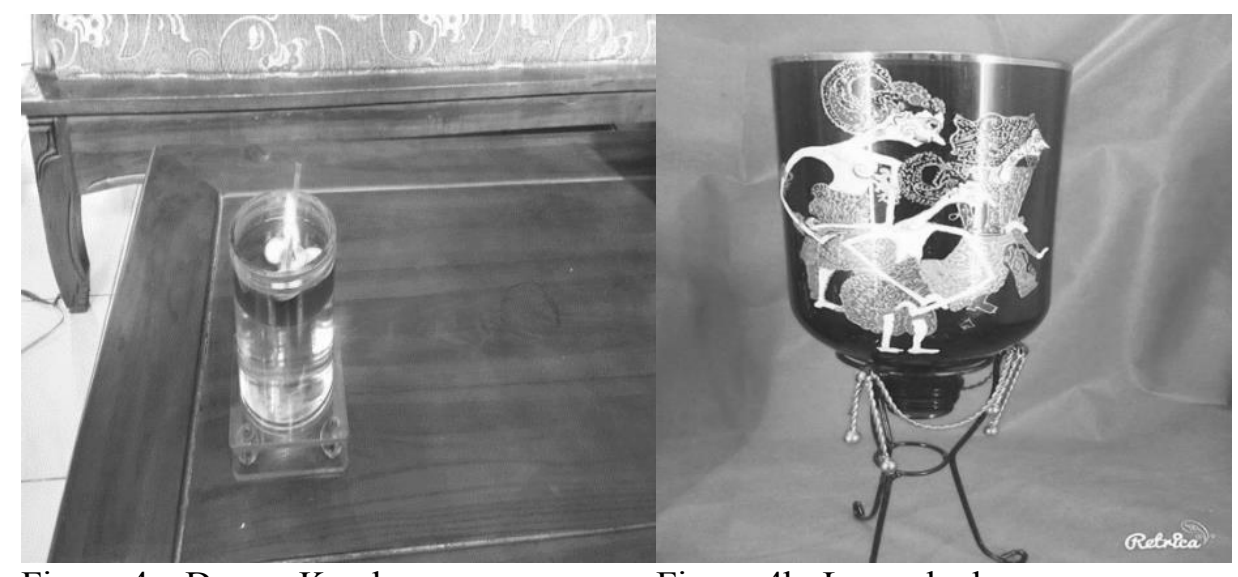

Figure 4a. Damar Kambang

Figure 4b. Lampshade

Figure 4a is a Damar Kambang (oil lamp) using glass bottle. The fuel used cooking oil and water, to avoid too much heat, while for the burner is rubber tied with used tin. Figure $4 \mathrm{~b}$ shows a lampshade with a large glass bottle placed on a steel mat. The glass bottle uses ornament of a Javanese puppet. The recycled craft is a recycling product and the work process involves rag pickers as suppliers of raw materials. Other AKPW souvenir handicraft products are Puspa Sarira puppets known as wayang suket, which is shown in Figure 5.

Ibu Suli states that the puppets are made from some sort of natural fibres, usually called as mendong by the locals. Puppets in Javanese culture are a work of art full of philosophy and are used a means of learning in several elementary schools in East Java. Another activity is conducting training to make Damar Kambang at Bongkasa, Ubud, Bali. Other activities show the process of making Puspa Sarira with cultural network team. AKPW community activities are shown in Figure 6. 


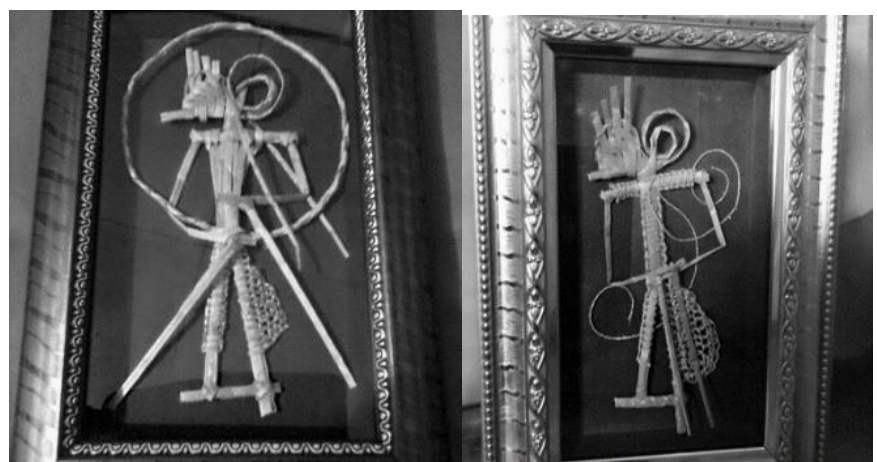

Figure 5. The Javanese Puppet of Puspa Sariro

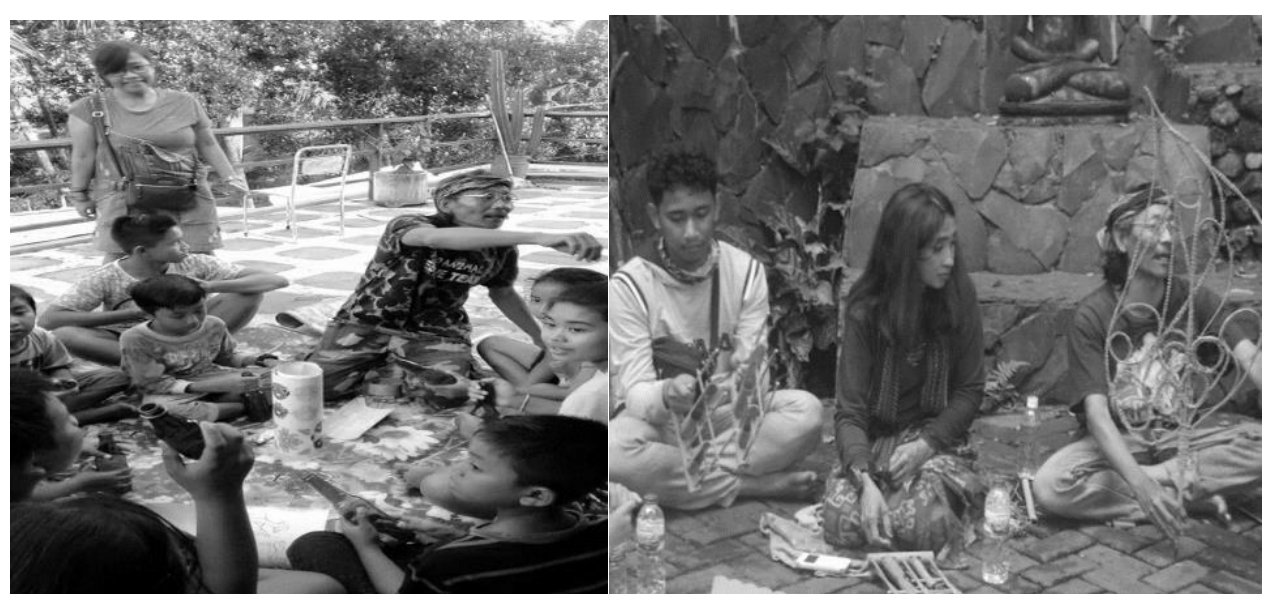

Figure 6. The Activities of Sanggar AKPW

AKPW is also actively involved in fostering street children affiliated with East Java Humanitarian Network (JKJT) and becomes a coach at Griya Baca belonging to Tri Jaya Lendra. These activities can be categorized as social entrepreneurship, i.e. creating a network with a humanitarian community and the coaching can provide business opportunities for their students. At this time, Damar Kambang has not found its market for the city people, but it becomes very useful for places of no electricity, such as temples or other places. Damar Kambang is environmentally friendly, safe, and efficient. The use of Damar Kambang in a temple is shown in Figure 7.

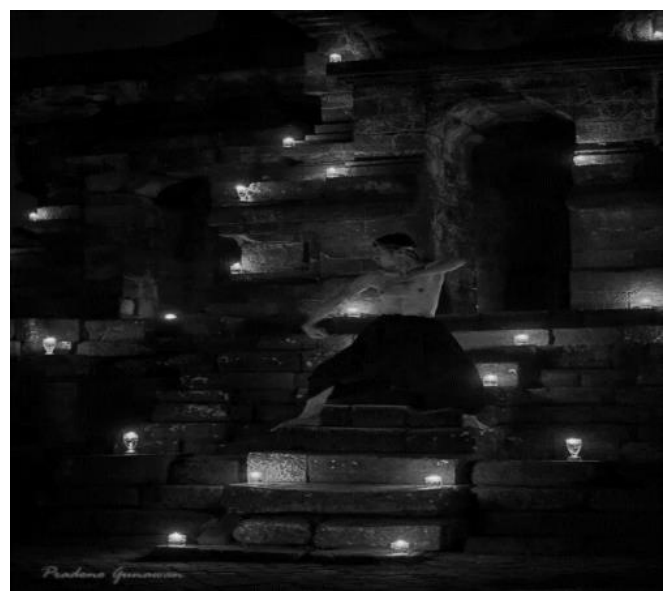

Figure 7. The Temple with Damar Kambang

\section{The Problems Faced by AKPW}

Here are the problems faced by AKPW according to the results of interview with Mrs. Suli:

a. Each member of AKPW has their own activities or jobs to do making it difficult for them to do their duties at AKPW optimally. 
b. Making handicrafts require patience and perseverance.

c. AKPW does not conduct online marketing through social media. It only sells the products to the referrals given by their acquaintance (word of mouth).

\section{AKPW Concept}

The combination of environment and social aspect results in environmental education through culture. The intersection between social and economic produces social entrepreneurship. Figure 8 presents the AKPW concept drawn from the above-mentioned discussions. S means sustainable, a sustainable sense between social, economic, and environmental systems as the objectives of AKPW Studio. E means Equable, in the sense of balance between social and economic aspects. Social aspects include the social conditions of AKPW community members in the cognitive, affective, and psychomotor domains, known through education and training to recycle and reuse of non-organic waste. The aim is to see the attitude and reason to act which generate the behaviour of AKPW community AKPW to for environmentally friendly recycle; this produces social entrepreneurship. B refers to Bearable, in terms of resilience between social and ecology, realized through the empowerment of members of AKPW to create environmentally friendly recycled crafts with non-organic waste materials and plants (grass). V means Viable, in the sense of continuing life or sustainability between economic and ecological aspects, embodies green entrepreneurship within AKPW community.

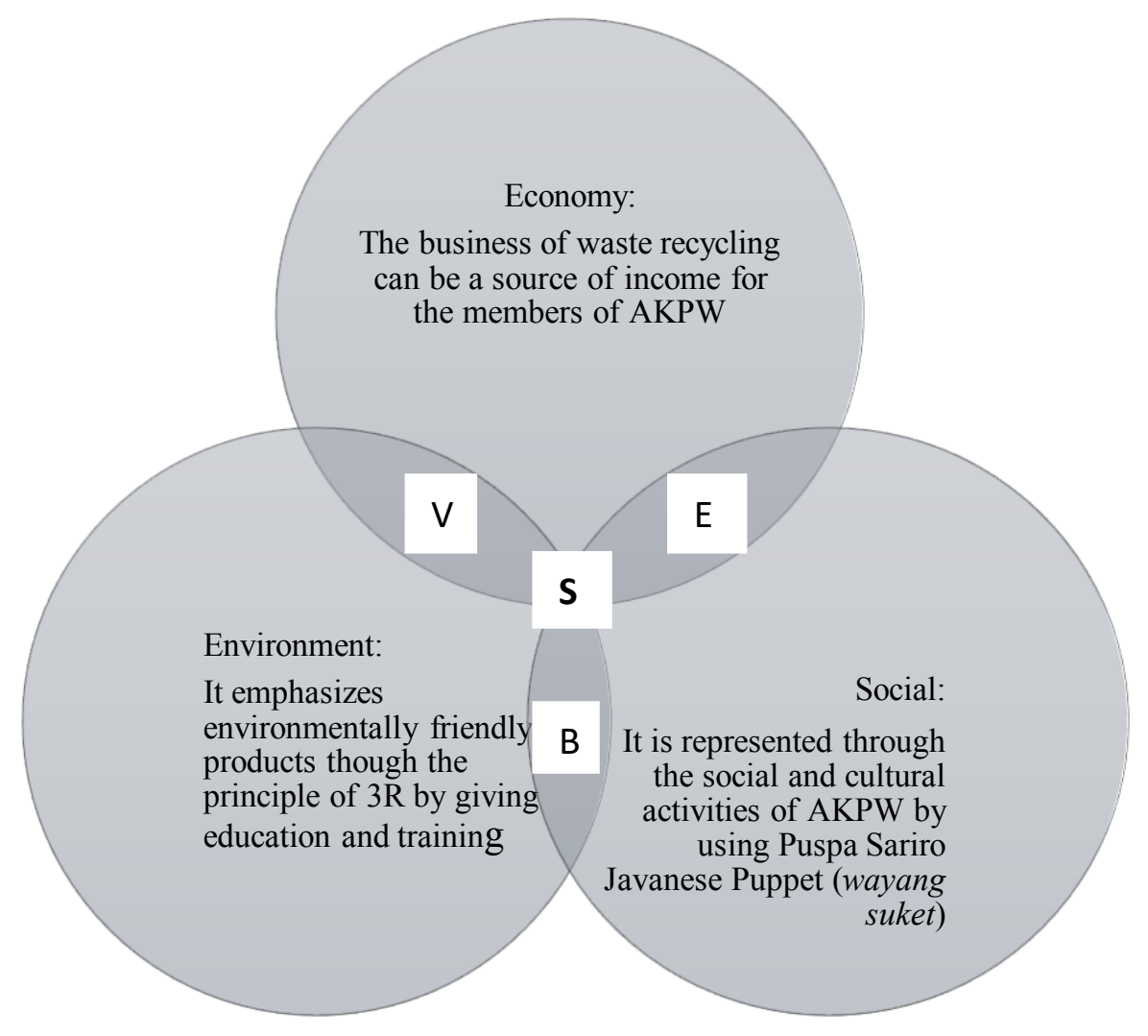

Figure 8. AKPW Concept: A Combination of Three Models of Sustainability and Entrepreneurial Pillars

\section{Conclusion}

Creativity is the key to produce the integration between behavioural attitude and sustainability as the goal of AKPW in making product innovation. This creativity is based on persistence and diligence represented through continuous experiment. To produce the recycled craft from non-organic waste needs talent because it relates to art. AKPW members are artists who prioritize artwork with high philosophy. Thus, their work is not sold online, because marketing needs a dialogue between the seller and the buyer with the involvement of taste and heart. 
Several conclusions can now be drawn from our investigation. Considering that products from AKPW are environmentally, socially and economically oriented, it uses three sustainability pillar model. Based on the attitudes and behaviours of the AKPW community, reasoning model is also used. It is based on attitude, subjective norms, and control of behaviour. Furthermore, the two models are used, formed agglomeration model with the centre of sustainability. Ecological or environmental safety has become the goal of AKPW, and this is manifested through education and training to make environmentally friendly craft. This is based on the beliefs and religious norms and becomes consciousness in the form of community service. In the social aspect, AKPW acts their way through by using puppet Puspa Sariro (wayang suket). Furthermore, from the economic aspect, the craft can be used as a source of family income. Thus, there is a connection between the environment and economy to produce green entrepreneurship.

The products of AKPW have not been widely known by the community in Malang, although the chairperson of AKPW is sometimes invited by other communities to provide training on recycling of non-organic waste. AKPW also makes a performance of Puspa Sariro which is known as wayang suket socialized to several elementary schools in East Java. However, the socialization is still limited because there are still many people who do not know the work of AKPW. It is suggested that AKPW be more active in socializing to the local, regional, national, and international community.

\section{References}

Ajzen, I. and M.Fishbein. (200o), "Attitude and the attitude-bhavior relation. Reason and aoutomatic processes”, In W. Stroebe and M. Hewstone (Eds.) European Review of Social Psychology, Vol. 11 No. x, pp. 1-33.

Bragiunsky, S., S.Klepper and Ohyama, A. (2009), "Schumpeterian Entrepreneurship. Departement of Social and Decision.Pittsburg", pp. 1-2.

Callan, S. and Thomas, J. (20oo), Environmental Economics E Management: Theory, Policy, and Applications, The Dryden Press, Harcourt College Publishers, USA.

Chell, E. (2007), "Social Enterprise and Entrepreneurship: Towards a Convergent Theory of the Entrepreneurial Process”, International Small Business Journal, Vol. 25 No. 1, pp. 5-26.

Dean, T.J. and McMullan, J.S. (2007), "Towards a theory of sustainable entrepreneurship: Reducing environmental degradation through entrepreneurial action”, Journal of Business Venturing, Vol. 22, pp. 50-76.

Gordon, W. (2011), "Behavioral economics and qualitative research-a marriage made in heaven?", International Journal of Market Research, Vol. 5 No. 2.

Hidup, K.L. (2008), Statistik Persampahan Indonesia, SWM Scoping Study, Jakarta.

Isaak, R. (2002), "The making of the ecopreneur", Greener Management International, Vol. 38, pp. 81-91.

Kahan, D. (2012), "Entrepreneurship in Farming", Farm Management Extention Guide, FAO, Rome.

Muljaningsih and Manzilati. (2001), Konsep Pemikiran Pengelolaan Sampah Perkotaan Secara Efektif E Efisien (Studi Di Kota Malang), FEUB, Malang.

O’Neill, G.D., Hershauer, J.C. and Golden, J.S. (2009), “The Cultural Context of Sustainability Entrepreneurship”, Greener Management International, Vol. 55, pp. 33-46.

Roedigar, T. and Schluga. (2004), The Porter Hypothesis and the Economic Consequences of Environmental Regulation. A Neo-Schumpeterian Approach, Edward Elgar Publishing, Inc, USA.

Tilley, F. and Young, W. (2009), "Sustainability Entrepreneurs: Could They Be the True Wealth Generators of the Future?”, Greener Management International, Vol. 55, pp. 79-92. 